\title{
Nutritional and Metabolic Alterations during Continuous Renal Replacement Therapy
}

\author{
Patrick M. Honoréa Elisabeth De Waele ${ }^{a} \quad$ Rita Jacobs $^{a} \quad$ Sabrina Mattens ${ }^{a}$ \\ Thomas Rose $^{a}$ Olivier Joannes-Boyau ${ }^{d} \quad$ Jouke De Regt ${ }^{a} \quad$ Lies Verfaillie $^{a}$ \\ Viola Van Gorp ${ }^{a}$ Willem Boer ${ }^{c}$ Vincent Collin ${ }^{b}$ Herbert D. Spapen ${ }^{a}$

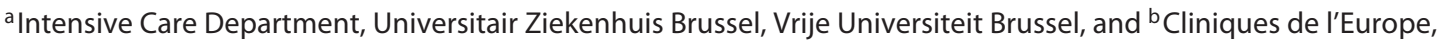 \\ Site St Michel, Brussels, and ' Department of Anaesthesiology and Critical Care Medicine, Ziekenhuis Oost-Limburg,

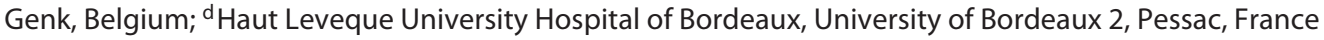

\begin{abstract}
Key Words
Continuous renal replacement therapy · Nutrition · Indirect calorimetry - Acute kidney injury - Calorie intake . Glutamine - Macronutrients - Micronutrients - Blood purification - Dialysis · Hemofiltration - Sepsis - Systemic inflammatory response syndrome - Dialytrauma .

Continuous renal replacement therapy trauma
\end{abstract}

\begin{abstract}
Adequate feeding of critically ill patients under continuous renal replacement therapy (CRRT) remains a challenging issue. We performed a systematic search of the literature published between 1992 and 2012 using the quorum guidelines regarding nutrition in intensive care unit patients treated with CRRT. Daily recommended energy requirements during CRRT are between 25 and $35 \mathrm{kcal} / \mathrm{kg}$ with carbohydrates and lipids accounting for $60-70 \%$ and $30-40 \%$ of calorie intake, respectively. Daily protein needs range from 1.5 to $1.8 \mathrm{~g} / \mathrm{kg}$. Indirect calorimetry corrected for CRRT-induced $\mathrm{CO}_{2}$ diversion should be used to more correctly match calorie intake to the real needs. This type of tool is not yet available but hopefully soon. Electrolyte deficit as well as overload have been described during CRRT but, in general, can be easily
\end{abstract}

controlled. Although not strongly evidenced, consensus exists to supplement important micronutrients such as amino acids (glutamine), water-soluble vitamins and trace elements.

Copyright $\odot 2013$ S. Karger AG, Basel

\section{Introduction}

Feeding patients with acute kidney injury (AKI), especially when treated with continuous renal replacement therapy (CRRT), remains a delicate yet challenging task for intensive care unit (ICU) clinicians. Indeed, the AKI process itself is accompanied by inherent metabolic and physiological disturbances necessitating careful implementation of ICU feeding protocols. CRRT allows volume removal and permits quasi unrestricted feeding. On the other hand, CRRT may cause considerable modifications in the nutritional 'household' by inducing substantial and incompletely quantified losses of macro- and micronutrients $[1,2]$. CRRT allowing clearance of low-molecularweight water-soluble substances implies significant loss of glucose, amino acids, low-molecular-weight proteins, trace elements, and water-soluble vitamins. Nonselective

\section{KARGER}

E-Mail karger@karger.com

www.karger.com/bpu
(C) 2013 S. Karger AG, Basel

0253-5068/13/0354-0279\$38.00/0
Prof. Patrick M. Honoré, MD, PhD

Intensive Care Department, Universitair Ziekenhuis Brusse

Vrije Universiteit Brussel (VUB)

BE-1090 Brussels (Belgium)

E-Mail Patrick.Honore@ uzbrussel.be 
molecular transport through CRRT membranes also enhances plasma clearance of certain blood components at elimination rates varying with operational characteristics. Recent studies in ICU patients underscored the positive correlation between hemofiltration dose and magnitude of these losses. If not recognized and corrected in time, depletion of specific substances will become harmful for the patient. We performed a systematic search of the literature published between 1992 and 2012 using the quorum guidelines regarding nutrition in ICU patients treated with CRRT. We concisely reviewed the current knowledge on nutrition during CRRT, with particular focus on observed losses of important or vital macro- and micronutrients. This search enabled us to provide some recommendations for daily nutrition management as well as nutrient supplementation in CRRT practice.

\section{Global Energy and Protein Requirements}

Recommended daily energy and protein requirements during CRRT range from 25 to $35 \mathrm{kcal} / \mathrm{kg}$ (with proportionally $60-70 \%$ carbohydrates and $30-40 \%$ lipids) and from 1.5 to $1.8 \mathrm{~g} / \mathrm{kg}$ body weight, respectively [1-3].

\section{Electrolytes}

Hypokalemia is present in 5-25\% of patients treated with CRRT [4-6] and is mainly due to inadequate potassium supplementation. Paradoxically, potassium loss is easily avoided either by using potassium-rich replacement fluids in hemofiltration, altering potassium concentration in the substitution fluid or administration of potassium supplements. Serum potassium levels below $3 \mathrm{mEq} / \mathrm{l}$ should absolutely be avoided as rapid correction may increase mortality [7]. Clinicians typically tend to avoid hyperkalemia in patients on CRRT. However, if hypervolemia is the main indication for initiating CRRT, hyperkalemia usually is innocuous and potassium substitution within the normal blood concentration range should be encouraged [6]. Low potassium-containing fluids are only mandatory in markedly life-threatening hyperkalemia.

The incidence of hypophosphatemia during CRRT varies between 10.9 and 65\% [4-6]. Its clinical effect remains poorly defined, yet phosphorus is involved in many vital functions such as tissue support, enzymatic processes, oxygen transport and energy transfer. Hypophosphatemia has been associated with failure to wean from me- chanical ventilation in medical ICU patients [8]. Adding phosphorus to substitution fluids is safe and adequately compensates undesired losses [9]. Commercial fluids containing physiological phosphate concentrations are to be preferred because they permit minimalization of the contamination risk and avoidance of eventual dosing errors when using 'homemade' solutions [9]. To compensate phosphorus loss, either intravenous bolus or enteral supplements can be administered. Special emphasis should be given whenever refeeding syndrome is suspected [10]. Recommendations do suggest that phosphate levels should be controlled at least twice daily during CRRT [11].

Regarding phosphorus behavior during CRRT and refeeding syndrome, we can say that not only the dose but also the duration of CRRT does affect phosphate levels. Ratanarat et al. [12] demonstrated that phosphate transfer during an intermittent hemodialysis session was little more than half the one observed during a 24-hour CRRT treatment, despite a fourfold higher clearance. This underlines the role of phosphate redistribution in relation to the duration of the used technique. Therefore, phosphate supplementation during refeeding syndrome and CRRT would require special attention of the attending physician as dose and especially duration will dramatically affect phosphate stores $[11,12]$.

Hyperphosphatemia rarely occurs during CRRT and, if present, requires increased clearance and the use of phosphate-free dialysis fluids. Phosphate is largely located intracellularly. Thus, a persistently high phosphorus level during CRRT may be a marker of massive intracellular necrosis (e.g. severe bowel ischemia) $[11,13]$. Hypomagnesemia is rarely seen $(<3 \%)$ and easily corrected with either commercially available fluids or daily administration of 2-4 g intravenous magnesium salt boluses [14]. Regarding calcium, hypocalcemia is commonly reported as a side effect with an incidence of up to $50 \%$ in some case series [11-14]. With the rising use of diluted citrate [11], calcium is more easily corrected as compared to the heparin era [11]. It has also been shown that hypercalcemia can be more easily controlled by CRRT and especially by avoiding rebound hypercalcemia [11-14]. Lastly, we have to briefly mention the techniques that are able to minimize those important substrate losses. Cascade hemofiltration [15] allows the ultrafiltrate to return first to a second filter (with small porosity) in order to prevent major losses of nutrients, antibiotics and other vital substances before the ultrafiltrate of this second low-cutoff filter returns to the patient's venous circuit [15]. Cascade hemofiltration was 
developed to limit losses of nutrients, antibiotics and other vital substances when performing high-volume hemofiltration [15].

\section{Specific Nutritional Compounds}

\section{Carbohydrate}

Carbohydrate loss during CRRT is not well documented, yet unquestionably relevant. Glucose loss can be estimated by multiplying the glucose concentration measured in an aliquot of effluent with the total daily effluent volume. Frankenfield et al. [16] prospectively studied glucose dynamics in polytrauma patients undergoing dextrose-free continuous hemodiafiltration with or without the addition of dextrose-containing fluids. Glucose loss reached $82 \pm 61 \mathrm{~g} /$ day when glucose-containing fluids and $57 \pm 22 \mathrm{~g} /$ day when glucose-free fluids $(\mathrm{p}<0.05)$ were used. A net positive uptake, though less expressed in the dextrose-free cohort, was detected in both groups [16]. Still, adding glucose to CRRT solutions may be problematic and CRRT mass transfer dynamics for glucose are insufficiently clarified. Supplementing glucose to the replacement fluid may produce a net glucose uptake as high as $300 \mathrm{~g} /$ day in patients under CRRT. This amount of glucose is the highest permitted to obviate hepatic lipid accumulation which disturbs liver metabolism [17]. Since the publication of these results, however, the application of CRRT underwent considerable changes such as a shift towards venovenous modalities and a substantial increase in hemofiltration dose. Nonetheless, we can assume that the use of glucose-free solutions produces a small and predictable glucose loss and that glucose-containing solutions will cause a positive glucose intake, making losses in the circuit less predictable. When glucose was added to the substitution fluid, a progressive increase in glucose concentration was noted with linear increments in net glucose transfer to the patient [18]. Whether glucose-enriched solutions eventually affect ultrafiltration capacity and dose delivery during high-flux hemodiafiltration with polysulphone membranes is poorly studied [19]. Finally, both higher plasma glucose levels and a higher glucose turnover have been described when lactate-based solutions are employed [20]. Although it remains unclear if glucose losses should be compensated, current evidence suggests that keeping glycemia within the normal range is beneficial. Most routinely used substitution fluids do contain dextrose and strict glycemia control during CRRT is thus essential. Special attention is needed when nutrition (in particular enteral nutrition) is withdrawn in case

Nutritional and Metabolic Alterations during CRRT of hypoglycemia because glucose is easily removed from the plasma. In the future, continuous glucose monitoring in patients on extracorporeal treatment, including CRRT, may be the best option to anticipate for dysglycemia problems [21].

\section{Protein and Nitrogen}

CRRT produces a significant nitrogen loss which, if not properly supplemented, may result in a nitrogen 'deficit'. Amino acids have different rates of elimination during extended CRRT and losses need to be counterbalanced by increasing the amino acid supply by approximately $0.2 \mathrm{~g} / \mathrm{kg} /$ day [1]. Moreover, Bellomo et al. [3] even suggested an amino acid supply of up to $2.5 \mathrm{~g} / \mathrm{kg} /$ day to assure a positive nitrogen balance in these highly catabolic patients. Since nutritional support is not volumelimited during CRRT, adequate amounts of protein can be provided to compensate for losses. Addition of glutamine (alanyl-glutamine dipeptide $0.3-0.6 \mathrm{~g} / \mathrm{kg} /$ day) to total parenteral nutrition, especially during CRRT, is recommended by the European Society of Parenteral and Enteral Nutrition (ESPEN) [22].

\section{Lipids}

AKI is associated with increased triglyceride content of low-density lipoproteins, altered lipolysis and reduced hepatic lipase activity. Taken together, this impaired lipid metabolism may cause an up to $50 \%$ decrease of lipid, and especially triglyceride, clearance. This enhances the risk of hyperglycemia particularly in parenterally fed patients $[1,2]$. Due to lower breakdown, triglycerides accumulate in AKI patients. Triglyceride overload becomes problematic when parenteral nutrition is started and is not resolved by CRRT because the very high molecular weight of these substances precludes filtration [23]. Thus, triglyceride levels need close monitoring in patients with AKI treated by CRRT especially when receiving parenteral nutrition. Both high molecular weight and inherent lack of water solubility preclude lipid elimination by CRRT. Lipids may also become involved in early packing or clotting of filters when unfractionated heparin is used as anticoagulant. This is seen less with citrate [24].

\section{Water-Soluble Vitamins and Trace Elements}

Patients with AKI are prone to depletion of trace elements. Reasons are multifactorial and include variable protein binding, redistribution between plasma and tissues, acute loss of biological fluids, dilution, varying concentrations of trace elements in dialysis/hemofiltration 
Table 1. Recommendations (summary)

\begin{tabular}{|c|c|c|}
\hline Energy & $\begin{array}{l}\text { Indirect calorimetry } \\
25-35 \mathrm{kcal} / \mathrm{kg} \text { body weight/day }\end{array}$ & $\begin{array}{l}60-70 \% \text { carbohydrates } \\
30-40 \% \text { lipids }\end{array}$ \\
\hline Protein & $1.5-1.8 \mathrm{~g} / \mathrm{kg}$ body weight/day & \\
\hline \multicolumn{3}{|l|}{ Electrolytes } \\
\hline $\mathrm{K}$ & serum level $>4 \mathrm{mEq} / \mathrm{l}$ & i.v. supplements \\
\hline & & K-rich replacement fluid \\
\hline & & K-rich substitution fluid \\
\hline $\mathrm{P}$ & & i.v. supplements \\
\hline & & $\begin{array}{l}\text { substitution fluid } \\
\text { enteral supplements }\end{array}$ \\
\hline $\mathrm{Mg}$ & & i.v. bolus $2-4 \mathrm{~g} /$ day \\
\hline Glucose & & strict glycemia control \\
\hline Amino acid & $\begin{array}{l}+0.2-2.5 \mathrm{~g} / \mathrm{kg} \text { body weight/day } \\
\text { glutamine (alanyl-glutamine dipeptide) } \\
0.3-0.6 \mathrm{~g} / \mathrm{kg} \text { body weight/day }\end{array}$ & \\
\hline Lipids & & close triglyceride monitoring \\
\hline \multicolumn{3}{|l|}{ Vitamins } \\
\hline Water-soluble & $\begin{array}{l}\text { vitamin } B_{1}: 100 \mathrm{mg} / \text { day } \\
\text { vitamin } B_{2}: 2 \mathrm{mg} / \text { day } \\
\text { vitamin } B_{3}: 20 \mathrm{mg} / \text { day } \\
\text { vitamin } B_{5}: 10 \mathrm{mg} / \text { day } \\
\text { vitamin } B_{6}: 100 \mathrm{mg} / \text { day }\end{array}$ & $\begin{array}{l}\text { vitamin } B_{7} \text { (biotin): } 200 \mathrm{mg} / \text { day } \\
\text { vitamin } B_{9} \text { (folic acid): } 1 \mathrm{mg} / \text { day } \\
\text { vitamin } B_{12}: 4 \mu \mathrm{g} / \text { day } \\
\text { vitamin } C: 250 \mathrm{mg} / \text { day }\end{array}$ \\
\hline Fat-soluble & $\begin{array}{l}\text { vitamin E: } 10 \mathrm{IU} / \text { day } \\
\text { vitamin K: } 4 \mathrm{mg} / \text { week }\end{array}$ & $\begin{array}{l}\text { vitamin } \mathrm{A} \text { : } \\
\text { reduce supplementation }\end{array}$ \\
\hline Trace elements & $\begin{array}{l}\text { selenium: }+100 \mu \mathrm{g} / \mathrm{day} \\
\text { zinc: } 50 \mathrm{mg} / \text { day } \\
\text { copper: } 5 \mathrm{mg} / \text { day }\end{array}$ & $\begin{array}{l}\text { triple dose of i.v. trace elements- } \\
\text { containing solutions }\end{array}$ \\
\hline Body temperature & $>37^{\circ} \mathrm{C}$ & \\
\hline
\end{tabular}

fluids, nutrient intake, and removal from plasma by CRRT [25-27]. Water-soluble vitamin and trace element losses and requirements during CRRT remain the subject of debate and research. Whole blood concentrations of these substances are not directly associated with removal. Also, the clinical significance of these losses remains unclear. In general, water-soluble vitamins are highly removed by CRRT (e.g. $68 \mathrm{mg}$ vitamin C and 290 $\mu \mathrm{g}$ folic acid per day) [25]. Proposed recommendations for daily supplementation of water-soluble vitamins are: $100 \mathrm{mg}$ vitamin $B_{1}, 2 \mathrm{mg}$ vitamin $B_{2}, 20 \mathrm{mg}$ vitamin $B_{3}$, $10 \mathrm{mg}$ vitamin $B_{5}, 200 \mathrm{mg}$ biotin, $1 \mathrm{mg}$ folic acid, $4 \mu \mathrm{g}$ vitamin $B_{12}$, and $250 \mathrm{mg}$ vitamin $C$ [28]. Vitamin $C$ intake in patients with AKI should not exceed the recommended dose because of the potential risk of nephrotoxic secondary oxalosis $[26,29]$. Thiamine loss may largely exceed the daily provision of this vitamin by standard total parenteral nutrition. Therefore, recommended sup- plements may vary accordingly $[1,30]$. The fat-soluble vitamins $\mathrm{E}$ and $\mathrm{K}$ also need to be supplemented (10 IU/ day and $4 \mathrm{mg} /$ week), respectively [30] but vitamin A must be reduced to compensate for deficient retinol degradation. Daily parenteral supplementation with standard doses of trace elements is supposed to compensate for CRRT removal [29]. However, the optimal dose of (multi-)trace element preparations in patients on CRRT is currently unknown. Trace element losses are most often intercepted by tripling the dose of currently available intravenous trace element-containing solutions, even in enterally fed patients. Among the trace elements, selenium may become significantly depleted during CRRT. Therefore, an additional intravenous dose of $100 \mu \mathrm{g}$ (at least 20-60 $\mu \mathrm{g}$ ) selenium should be administered daily during CRRT [31]. To date, supplementation of vitamins and trace elements during CRRT has shown no proven benefit on survival $[1,26,29]$. 


\section{Heat and Energy Loss}

Higher CRRT doses are associated with a higher incidence of hypothermia [32]. CRRT-induced body cooling is determined both by the time during which blood circulates outside the body and the contact with cold dialysate and/or replacement fluids. Long-term body cooling may have unwarranted or potentially detrimental side effects such as energy loss, shivering with increased oxygen demand, vasoconstriction, impairment of leukocyte function, and coagulation disorders [32]. As a consequence, monitoring of body temperature is imperative. If the incorporated CRRT heating system fails to maintain the desired core temperature, external heating aiming at a temperature above $37^{\circ} \mathrm{C}$ (and sometimes even close to $42^{\circ} \mathrm{C}$ ) must be utilized [32]. Of note, cooling may beneficially affect hemodynamics and outcome in ICU patients [33]. As such, CRRT has proven useful to quickly establish hypothermia in certain conditions (e.g. cardiac arrest induced by ventricular fibrillation) [34].

CRRT provokes a heat loss of approximately 1,000 $\mathrm{kcal} /$ day [33], which must be considered into the energy balance account. On the contrary, and especially during shock, overzealous hypothermia may be deleterious for myocardial function and should be carefully monitored especially also regarding clothing and platelet count [33, 34]. Ideally, energy requirements should be measured by indirect calorimetry to more correctly match the amount of delivered calories to the patient's needs [35]. Indirect calorimetry, however, remains difficult to perform during CRRT because the CRRT-induced bicarbonate/ $\mathrm{CO}_{2}$ diversion renders the measurement unreliable [36]. At room temperature, CRRT produces loads of $\mathrm{CO}_{2}$. This production will increase during active rewarming of the substitution fluid or the blood itself. In other words, during CRRT, $\mathrm{CO}_{2}$ production no longer reflects the metabolic production of the body because substantial amounts of $\mathrm{CO}_{2}$ are produced by the transformation of bicarbonate during CRRT [36]. To overcome this inconvenience, indirect calorimetry could be performed when the patient is off CRRT. Currently, we conduct a randomized crossover study comparing indirect calorimetry in patients on and off CRRT, using patients within one study group as their own controls. The major aim is to quantify the bicarbonate $/ \mathrm{CO}_{2}$ diversion and to determine a factor for correcting indirect calorimetry results during CRRT [unpubl. data]. More generally speaking, dose is by far the most important item that may interfere with nutrition needs. Intermittent hemodialysis does obviously need completely different guidelines.

Nutritional and Metabolic Alterations during CRRT
Regarding the different modalities (CVVH, CVVHD, CVVHDF, etc.), differences are tiny as long as the dose is the same amongst the various modalities. The only differences are concerning electrolytes although the recent work of the group of Bellomo did show that CVVHD or CVVHDF was not superior to CVVH if the same dose was applied even regarding electrolytes clearance [3638]. It is really the dose that would make the major difference regarding nutrition guidelines [36]. Regarding membranes, highly adsorptive membranes are more prone to adsorb antibiotics but this remains an area of research up to now [36]. Regarding high-cutoff membranes, we do not have data right now regarding this issue [36].

\section{Conclusions}

Loss of macro- and micronutrients is well documented during CRRT and, in general, requires replenishing or compensating eventual deficits. The final aim should be to optimize the nutritional status of the patient and to reduce the so-called 'dialytrauma' induced by CRRT [37]. Daily recommended energy requirements during CRRT fluctuate between 25 and $35 \mathrm{kcal} / \mathrm{kg}$ (60-70\% carbohydrates and $30-40 \%$ lipids) and between 1.5 and $1.8 \mathrm{~g} / \mathrm{kg}$ protein [1-3]. Significant alterations of carbohydrate and lipid metabolism as well as severe electrolyte disturbances may be found in patients undergoing CRRT. Close monitoring of these metabolic parameters and their interactions is imperative. Energy requirements during CRRT are increased and should best be assessed by indirect calorimetry. However, this technique is not universally available and will need correction for the known bicarbonate $/ \mathrm{CO}_{2}$ diversion induced by CRRT. The current ESPEN guidelines allow us to adequately supplement important micronutrients such as amino acids (glutamine), water-soluble vitamins and trace elements. More widespread recognition of 'dialytrauma' and the use of an appropriate checklist (table 1) may help the bedside clinician to better assess and handle nutrition deficits in CRRT patients [38].

Blood Purif 2013;35:279-284

DOI: $10.1159 / 000350610$ 


\section{References}

$>1$ Wiesen P, Van Overmeire L, Delanaye P, Dubois B, Preiser JC: Nutrition disorders during acute renal failure and renal replacement therapy. J Parenter Enteral Nutr 2011;35:217222.

2 Leverve X, Cano NJM: Nutritional Management in Acute Illness and Acute Kidney Insuffiency. Contrib Nephrol. Basel, Karger, 2010, vol 156, pp 112-118.

$\checkmark 3$ Bellomo R, Tan HK, Bhonagri S et al: High protein intake during continuous hemodiafiltration: impact on aminosides and nitrogen balance. Int J Artif Organs 2002;25:261-268.

4 Palewsky PM, Zhang JH, O’Connor TZ, Chertow GM, Crowley ST, Choudury D, et al, for the VA/NIH Acute Renal Trial Network: Intensity of renal support in critically ill patients with acute kidney injury. N Engl J Med 2008;359:7-20

$\checkmark 5$ RENAL Replacement Therapy Study Investigators, Bellomo R, Cass A, Cole L, Finfer S, Gallagher M, Lo S, McArthur C, McGuinness S, Myburgh J, Norton R, Scheinkestel C, Su S: Intensity of continuous renal-replacement therapy in critically ill patients. N Engl J Med 2009;361:1627-1638.

6 Prowle JR, Bellomo R: Continuous renal replacement therapy: recent advances and future research. Nat Rev Nephrol 2010;6:521529.

7 Santoro A, Mancini E, London G, et al: Patients with complex arrhythmias during and after haemodialysis suffer from different regimens of potassium removal. Nephrol Dial Transplant 2008;23:1415-1421.

$>8$ Alsumrain MH, Jawad SA, Imran NB, Riar S, DeBari VA, Adelman M: Association of hypophosphatemia with failure-to-wean from mechanical ventilation. Ann Clin Lab Sci 2010; 40:144-148.

9 Troyanov S, Geadah D, Ghannoum M, Cardinal J, Leblanc M: Phosphate addition to hemodiafiltration solutions during continuous renal replacement therapy. Intensive Care Med 2004;30:1662-16

10 Machado JD, Suen VM, Chueire FB, Marchini JF, Marchini JS: Refeeding syndrome, an undiagnosed and forgotten potentially fatal condition. BMJ Case Rep 2009; epub 2009 Mar 5.

-11 Honore PM, Jacobs R, Joannes-Boyau O, et al: Septic AKI in ICU patients. Diagnosis, pathophysiology, and treatment type, dosing, and timing: a comprehensive review of recent and future developments. Ann Intensive Care 2011;9:1:32.

12 Ratanarat R, Brendolan A, Volker G, et al: Phosphate kinetics during different dialysis modalities. Blood Purif 2005;23:83-90.

$\checkmark 13$ Lochy S, Jacobs R, Honore PM et al: Phosphate induced crystal acute kidney injury: an underrecognized cause of chronic kidney disease. Case report and review of the literature. Int J Nephrol Renovasc Dis 2013;6:61-66.
14 Uchino S, Bellomo R, Morimatsu H, et al: Continuous renal replacement therapy. A worldwide practice survey. The Beginning and Ending Supportive Therapy for the Kidney (BEST Kidney) investigators. Intensive Care Med 2007;33:1563-1570.

15 Rimmelé T, Wey PF, Bernard N, Monchi M et al: Hemofiltration with the cascade system in an experimental porcine model of septic shock. Ther Apher Dial 2009;13:63-70.

16 Frankenfield DC, Reynolds HN, Badellino MM, Wiles CE: Glucose dynamics during continuous hemodiafiltration and total parenteral nutrition. Intensive Care Med 1995; 21:1016-1022.

17 Monaghan R, Watters JM, Clancey SM, Moulton SB, Rabin EZ: Uptake of glucose during continuous arteriovenous hemofiltration. Crit Care Med 1993;21:1159-1163.

18 Bonnardeaux A, Pichette V, Ouimet D, Geadah D, Habel F, Cardinal J: Solute clearances with high dialysate flow rates and glucose absorption from the dialysate in continuous arteriovenous hemodialysis. Am J Kidney Dis 1992;19:31-38.

19 Vaussenat F, Canaud B, Bosc JY, Leblanc M, Leray-Moragues H, Garred LJ: Intradialytic glucose infusion increases polysulphone membrane permeability and post-dilutional haemodiafiltration performances. Nephrol Dial Transplant 2000;15:511-516.

20 Bollmann MD, Revelly JP, Tappy L, et al: Effect of bicarbonate and lactate buffer on glucose and lactate metabolism during hemodiafiltration in patients with multiple organ failure. Intensive Care Med 2004;30:1103-1110.

21 Javid PJ, Halwick DR, Betit P, et al: The first use of live continuous glucose monitoring in patients on extracorporeal life support. Diabetes Technol Ther 2005;7:431-439.

22 Singer P, Berger MM, Van den Berghe G, Biolo G, Calder P, Forbes A, Griffiths R, Kreyman G, Leverve X, Pichard C: ESPEN Guidelines on Parenteral Nutrition: intensive care. Clin Nutr 2009;28:387-400.

23 Stefanutti C, Di giacoma S, Labbadia G: Timing clinical events in the treatment of pancreatitis and hypertriglyceridemia with therapeutic plasmapheresis. Transf Aphrer Sci 2011;45:3-7.

24 Kazory A, Clapp WL, Ejaz AA, Ross A: Shortened hemofilter survival time due to lipid infusion in continuous renal replacement therapy. Nephron Clin Pract 2008;108:5-9.

25 Story DA, Ronco C, Bellomo R: Trace elements and vitamin concentration and losses in critically ill patients treated with continuous venovenous hemofiltration. Crit Care Med 1999;27:220-223.

26 Berger MM, Shenkin A, Revelly JP, et al: Copper, selenium, zinc, and thiamine balances during continuous venovenous hemodiafiltration in critically ill patients. Am J Clin Nutr 2004;80:410-416.
27 Klein CJ, Nielsen FH, Moser-Veillon PB: Trace elements loss in urine and effluent following traumatic injury. J Parenter Enteral Nutr 2008;32:129-139.

28 Cano NJ, Aparicio M, Brunori G, Carrero JJ, Cianciaruso B, Fiaccadori E, Lindholm B, Teplan V, Fouque D, Guarnieri G: ESPEN Guidelines on Parenteral Nutrition: adult renal failure. Clin Nutr 2009;28:401-414.

29 Chiolero R, Berger MM: Nutritional Support during Renal Replacement Therapy. Contrib Nephrol. Basel, Karger, 2007, vol 156, pp $267-$ 274.

30 Honore PM: Macronutrients and micronutrients requirements during CRRT. An update. Proc Ann Belg Nutr Symp 1999;10:45-61.

31 Lopez Martinez J, Sanchez-Izquierdo Riera JA, Jimenez Jimenez FJ: Guidelines for specialized nutritional and metabolic support in the critically-ill patient: update. Consensus of the Spanish Society of Intensive Care Medicine and Coronary Units and the Spanish Society of parenteral and Enteral Nutrition (SEMICYUC-SENPE): Acute Renal Failure. Med Intensiva 2011;35(suppl):22-27.

32 Yagi N, Leblanc M, Sokal K, Wright EJ, Paganini EP: Cooling effect of continuous renal replacement therapy in critically ill patients. Am J Kidney Dis 1998;32:1023-1030

33 Robert R, Mehaud JE, Timricht N, Goudet V, Mimoz O, Debaene B: Benefits of early cooling phase in continuous renal replacement therapy for ICU patients. Ann Intensive Care 2012;2:40.

34 Karacon H, Valentin A, Carl P: Mild therapeutic hypothermia after cardiac arrest through continuous dialysis. Ugeskr Laeger 2009;171:1395-1400.

35 Manns M, Maurer E, Steinbecht B, Elaly HG. Thermal energy balance during in vitro continuous hemofiltration. ASAIO J 1998;44: 601-605.

36 36)Honore PM, Jacobs R, Joannes-Boyau O et al: Newly designed CRRT membranes for sepsis and SIRS: a pragmatic approach for bedside intensivists summarizing the more recent advances. A systematic structured review. ASAIO J 2013;59:99-106.

37 De Waele E, Spapen H, Honoré PM, Mattens S, Rose T, Huyghens L: Bedside calculation of energy expenditure does not guarantee adequate caloric prescription in long-term mechanically ventilated critically ill patients: a quality control study. Scientific World J 2012; 2012:909564.

38 Maynar J, Honoré PM, Sanchez-Izquierdo JA, Herrera M, Spapen HD: Handling CRRT-related adverse effects in ICU patients: the dialytrauma concept. Blood Purif 2012;34:177187. 